\title{
Same-Sex Marriages and the Supreme Court: A Missed Opportunity in Revisiting Miscegenation Laws and Violations of U.S. Constitutional Laws and Statutes
}

\author{
Frances L. Edwards, J.D \\ Clemson University \\ 105 Sikes Hall, Clemson, SC 29634, United States
}

\section{Introduction}

In the 2015 landmark decision in Obergefell v. Hodges ${ }^{l}$ concerning same-sex marriages focused on the Fourteenth Amendment and the fundamental right to marry by both the Due Process Clause and the Equal Protection Clause. Requiring all states to issue marriage licenses to same-sex couples and recognizing same-sex marriages was a breakthrough in this most recent and controversial discrimination issue. Earlier the request by the Obama administration for the Supreme Court to declare void a provision of the Defense of Marriage Act (DOMA) ${ }^{2}$ had brought the possibility that same-sex marriages may finally be recognized. ${ }^{3}$ The administration cited that Section 3 of the Defense of Marriage Act denies federal benefits to legally married same-sex couples, while allowing such benefits to legally married heterosexual couples comes under attack that it violates the $14^{\text {th }}$ Amendment fundamental constitutional guarantee of "equal protection under the law." There is no doubt that marriage of same-sex couples have not been treated equally in the United States. Prior to the Supreme Court ruling 36 states and the District of Columbia and Guam had in certain cases legalized gay marriages to differing degrees. ${ }^{5}$

The arguments against discriminating against same-sex marriage usually fall under $4^{\text {th }}$ Amendment, $5^{\text {th }}$ Amendment and $14^{\mathrm{th}}$ Amendment protections. ${ }^{6}$ Lost in the mêlée of arguments are two legal concerns. Prohibitions or restrictions to those who are married to a member of the same sex violate Title VII of the Civil Rights Act of 1964 that explicitly protects against discrimination toward "any individual because of his race, color, religion, sex, or national origin." As an anecdote, for instance, after the 2014 ruling of the $4^{\text {th }}$ Circuit Court of Appeals in Bostic v. Schaefer ${ }^{8}$ in which Virginia's ban on same-sex marriage was found to be unconstitutional, two judges in South Carolina accepted marriage license applications from same-sex couples. This set off a maelstrom of legal activity in the state of South Carolina. In some parts of the state same- sex license applications were blocked. ${ }^{9}$ Such same-sex marriage prohibitions mirrored quite plainly the rationale and restriction of interracial marriage under anti-miscegenation laws. This article will analyze theories of inequality in the area of marriage of same-sex marriage. In particular, it will liken the legal theory underlying same-sex marriage prohibitions to the antiquated legal theory of anti-miscegenation laws - laws that have been struck down long ago by the Supreme Court of the United States.

\section{Miscengenation \& Same-Same Marriages}

Prohibitions against same-sex marriage ring of the rhetoric to the anti-miscegenation laws. These laws were generally defined as the marriage of persons of different races. However, the constitutional justifications of miscegenation

1576 U.S. S. (2015).

21 Defense of Marriage Act (DOMA) (Pub.L. 104-199, 110 Stat. 2419, enacted September 21, 1996, 1 U.S.C. § 7 and 28 U.S.C. $\$ 1738$ C, 1996.

${ }^{3}$ http://articles.washingtonpost.com/2013-02-23/politics/3725186_1_defense-of-marriage-act-obama-administration-gaymarriage.

${ }^{4}$ Section $1,14^{\text {th }}$ Amendment, Constitution of the U.S.

${ }^{5}$ Lyle Denniston, Opinion Analysis: Marriage Now Open to Same-Sex Couples”, SCOTUS, June 26, 2015 ,

http://www.scotusblog.com/2015/06/opinion-analysis-marriage-now-open-to-same-sex-couples/.

See also http://www.governing.com/gov-data/same-sex-marriage-civil-unions-doma-laws-by-state.html

${ }^{6}$ U.S. CONST. amend IV; U.S. CONST. amend V; U.S. CONST. amend X IV.

${ }^{7}$ Title VII of the Civil Rights Act, SEC. 2000e-2, Section 703 (1964). GOVERNING: The Sates and Localities, "State Same Sex Marriage State Laws Map, http://www.governing.com/gov-data/same-sex-marriage-civil-unions-doma-laws-bystate.html, e. Republic (2018)

8760 F.3d 352 (4th Cir. 2014).

${ }^{9}$ Kurtis Lee and James Queally, Judges in Kansas, South Carolina Set To Allow Gay Marriage Despite Bans, LA TIMES, October 8 2014, http://www.latimes.com/nation/nationnow/la-na-nn-samesex-marriage-south-carolina-20141008-story.html. 
statutes have much the same rational as prohibitions against same-sex marriages. In Virginia, it was ordered by the court in September 17, 1630 that a man named Hugh Davis "was to be "soundly whipped ... for abusing himself to the dishonor of God and the same of Christians, by defiling his body in lying with a negro. . ."10 Similar rhetoric has been used during in opposition to the In re Marriage case of the California Supreme Court on same-sex marriage. ${ }^{11}$ Opponents such as James Dobson, who is chairman of the conservative Christian organization, "Focus on the Family" vowed to fight the California court decision with a constitutional amendment. Calling the ruling an "outrage" he flared out an e-mail that said "(i)t will be up to the people of California to preserve traditional marriage by passing a constitutional amendment ...." The statement was followed by that "(o)nly then can they [the people of California] protect themselves from this latest example of judicial tyranny."

The largest Protestant denomination in the nation, Southern Baptist, passed a resolution in New Orleans on Tuesday, June 19, 2012 opposing same sex-marriages, saying it was not a Civil Rights issue. The resolution that marriage is "the exclusive union of one man and one women" and that "all sexual behavior outside of marriage is sinful," passed almost unanimously. ${ }^{13}$ The Episcopalian Church has also grappled with the sanctity of gay marriages. In July of 2012, conservatives of that church argued against gay-marriages, stating that the Bible speaks out against homosexuality, and that if the church "moves to embrace homosexuals, the Church is not acting according to [theological thinking], but is instead conforming to liberal chic". ${ }^{14}$ Even Supreme Court Justice Antonin Scalia blasted the concept of gay rights. He stated very clearly that gay rights is an easy case, along with abortion and the death penalty. In a statement at the American Enterprise Institute, he stated, "Homosexual sodomy? Come on. For 200 years, it was criminal in every state." 15

During the days of the miscegenation laws, courts argued that marriage contracts are "civil contracts" that should be left up to state law." "Further in the case of State v. Gibson the Indiana court ruled that "[t]he right in the states, to regulate and control, to guard, protect, and preserve this God-given, civilizing, and Christianizing institution is of inestimable importance and cannot be surrendered. . . ${ }^{17}$ The underlying "Christian principle" to the argument appears to be clear, both in the court decisions of the 1800's and the $21^{\text {st }}$ century arguments against freedom of individuals to choose a marriage partner. Both miscegenation and same-sex marriages appear to have an undertone of socially undesirable practices and the need of states to accomplish such outcomes through prohibitions. In the 1944 case of Stevens v. U.S. the federal court clearly stated that the states have certain rights to regulate specific areas such as domestic matters. The court stated: "The Fourteenth Amendment gives no power to Congress to interfere with the right of a state to regulate the domestic relations of its own citizens, and if a state enacts such laws . . . the federal courts must respect them as they stand, without inquiring into the reasons of them." ${ }^{18}$ However, in the famous Loving $v$. Virginia case the U.S. Supreme Court decided in 1967 that a law forbidding races to intermarry violated both the Due Process Clause and the Equal Protection Clause of the Fourteenth Amendment of the Constitution. In this case, Chief Justice Earl Warren's opinion to the unanimous court stated that "(m)arriage is one of the 'basic civil rights of man,' fundamental to our very existence and survival. . . . To deny this fundamental freedom on so unsupportable a basis as the racial classifications embodied in these statutes, classifications so directly subversive of the principle of equality at the heart of the Fourteenth Amendment, is surely to deprive all the State's citizens of liberty without due process of law. The Fourteenth Amendment requires that the freedom of choice to marry not be restricted by invidious racial discrimination. Under our Constitution, the freedom to marry, or not marry a person of another race resides with the individual and cannot be infringed by the State."19

\footnotetext{
${ }^{10} 1$ Laws of Virginia 146 (Hening 1823).

${ }^{11}$ In re Marriage Cases, 43 Cal. $4^{\text {th }}, 757$ (Cal. 2008).

${ }^{12}$ Lisa Leff, California Court Legalizes Gay Marriage, THE GREENVILLE NEWS, May 16, 2008, at 14A. To name-call this decision as “tyranny" would appear to anyone as a projection of Mr. Dobson's and others' in fact "tyranny" of wishing to limit lifestyle decisions through legal means of outlawing certain activities.

${ }^{13}$ Travis Loller, The Associated Press, "Southern Baptists Say Gay Marriage Isn't A Civil Right," THE GREENVILLE NEWS, Thursday, June 21, 2012, p. 4A.

${ }^{14}$ Jon Meacham, "Of God and Gays and Humility: What the Episcopal Church's Handling of Same-Sex Unions Can Teach the Rest of Us," TIME MAGAZINE, July 30, 2012, p. 16.

${ }^{15}$ Mark Sherman, Associated Press, "Scalia, Abortion, Gary Rights Are Easy Cases," THE GREENVILE NEWS, Saturday, October 6, 2012, p.4A.

${ }^{16}$ State v. Georgia. 29 GA 321. 328(1869).

1736 IND 389,402 (1871).

${ }^{18}$ Stevens v. U.S. 146 F. $2^{\text {nd }} 120\left(10^{\text {th }}\right.$ Cir. 1944)

${ }^{19} 388$ U.S. 1 (1967).
} 
If one would substitute the words "racial classification" to "sexual classification; "racial discrimination" to "sexual discrimination"; and "marry a person of another race" to "marry a person of the same sex", the legal argument is clear. Prohibitions against same-sex marriages are as insidious and discriminatory as the miscegenation laws and the Jim Crow Laws that have gone before them and have been struck down by the U.S. Supreme Court. In 2010 in Perry $v$. Schwarzennegger, which overturned California's Proposition 8 (restricting marriage to opposite-sex couples) Jude Vaughn R. Walker cited Loving $v$. Virginia to state that "the [constitutional\} right to marry protects an individual's choice of marital partner regardless of gender". ${ }^{20}$

\section{The Supreme Court of California on Same-Sex Marriages - 2008}

In 2008, The Supreme Court of California in the case of In re Marriage Cases $^{21}$ took a broader societal view of samesex marriages. The court looked at the more traditional view of the $4^{\text {th }}$ Amendment interpretations concerning samesex unions. It cited the $14^{\text {th }}$ Amendment equal protection under the law and also the 4th Amendment right to privacy, in its opinion that invalidated the California law ${ }^{22}$ that would ban same-sex marriages. ${ }^{23}$ The Fourth Amendment speaks of "[t]he right of the people to be secure in their persons, houses, . . . and effects. . .." 24 In the notable work by Dean Prosser, Professor Prosser spoke of privacy in a larger context of an individual's rights to be free on unwanted scrutiny and interference with one's private matters. Relating privacy to protected rights under tort law, Prosser stated that the invasion of the right to privacy and the protection of one's privacy included an unreasonable intrusion upon an individual's solitude. ${ }^{25}$ In Olmstead vs. United States, Supreme Court Justice Brandeis defined privacy as "a right to be left alone." ${ }^{26}$ The concept was stated in this famous 1928 Supreme Court Olmstead wiretap case. ${ }^{27}$ In this case, Justice Brandeis defined the right of privacy in a broader, more spiritual and personal nature concerning one's right to seclusion and private living free of governmental intervention. Justice Brandies stated that "the protection guaranteed by the amendments (of the Constitution) is much broader in scope. The makers of our Constitution undertook to secure conditions favorable to the pursuit of happiness. They recognized the significance of man's spiritual nature, of his feelings and of his intellect .... They sought to protect Americans in their beliefs, their thoughts, their emotions, and their sensations. They conferred as against the government the right to be left alone -- the most comprehensive of rights and the right most valued by civilized men." 28

Statutes that have limited marriage to those of the opposite sex often fail to justify such prohibitions against a background of the inherent right to privacy under the $4^{\text {th }}$ Amendment. Those statutes that rationalize such prohibitions based on the concept of procreation have listing logic. William Hohengarten noted that the right to procreate is not a requirement for opposite-sex marriages, nor is the inability to procreate invalidate the ability to opposite-sex couples to marry. ${ }^{29}$ He argues that the fundamental right to marry, is supported by the U.S. Supreme Court in Loving v. Virginia which states conclusively the freedom to choose a marriage partner (in this case despite fundamental and historical concepts that railed against interracial marriages). He urges that restricting this freedom to choose whom to marry is indeed unconstitutional. ${ }^{30}$ This is true as an overall principle under one's freedom of choice and the freedom to have one's privacy and private choices free from governmental intervention as protected by the $4^{\text {th }}$ Amendment of the Constitution.

\section{Title Vii Anti-Dicrimination and Same-Sex Marriage Laws}

Title VII of the Civil Rights Act of 1964 explicitly protects against discrimination toward "any individual because of his race, color religion, sex, or national origin." 31 Although "sex" is one of the protected areas, the Supreme Court has not been outspoken in defining sex as sexual preference or sexual identity.

\footnotetext{
${ }^{20}$ Perry v. Schwarzenegger, 704 F.Supp. $2^{\text {nd }} 921$ (N.D.Cal.2010).

${ }^{21}$ In re Marriage Cases, 43 Cal. $4^{\text {th }}, 757$ (Cal. 2008).

${ }^{22}$ Fam. Cole. Sections 300 and 3008.5 were held unconstitutional. Cal. Const. art. I. Sections 1 and 7 were held to guarantee same-sex couples the same substantive and constitutional rights as opposite-sex couples. Supra at 20.

${ }^{23}$ U.S. CONST. amend IV.

${ }^{24} \mathrm{Id}$.

${ }^{25}$ Dean Prosser, Privacy, 48 California Law Review 383. (1960).

26277 U.S. 438 (1928).

${ }^{27}$ Id.

${ }^{28}$ Id.

${ }^{29}$ William M. Hohengarten, "Same-sex Marriage and the Right to Privacy", THE YALE LAW JOURNAL, Yale University, School of Law, Vol. 103, No. 6, April 1, 2994, 1511-1513

${ }^{30}$ Id at 1506.

${ }^{31}$ Supra, note 7.

42
} 
Courts have skirted the issue and regulations have spoken of what may or may not be asked in regard to sexual preference in employment interviews, but any decisive leadership from the Supreme Court concerning discrimination of same-sex couples has not come forth.$^{32}$ As one author stated in 2004, "[c]urrently, there is no federal law that explicitly prohibits discrimination against lesbian, gay, bisexual, and transgender (LGBT) people. Title VII of the Civil Rights Act of 1964 outlaws hiring or employment discrimination on the basis of the employee's 'race, color, religion, sex, or national origin,' but does not mention sexual orientation, much less gender identity. ${ }^{33}$ Some courts after Pricewaterhouse v. Hopkins started to support and protect transgender employees from discrimination but only for of sex stereotyping. ${ }^{34}$ The Second and Seventh Circuit courts held that Title VII prohibits sexual orientation discrimination. ${ }^{35}$ These courts have followed Pricewaterhouse attempts to amend Title VII or to enact new, freestanding federal legislation to prohibit discrimination due to sexual orientation go back almost thirty years. The first such attempt - to add the phrase "affectional or sexual preference" was made in $1975 .{ }^{36}$ To date, no bill specifically prohibiting employment discrimination on the basis of gender identity has been passed on the federal level. In addition, to date there is no amendment to Title VII concerning this kind of discrimination.

It was a likely argument by proponents of prohibitions against same-sex marriages is that this discriminatory same-sex subject is in the public domain of employment. How nonsensical is an argument that if the law excludes discrimination in the very public employment market, nevertheless there can be laws that discriminate against a class of people regarding their private matters. Although Obergefell $v$. Hodges ${ }^{37}$ legalized same sex marriages, this case, in its rationale did not find fit to discuss protections against discrimination concerning sexual preference or sexual identity in the workplace as a comparative issue. This illogical application of laws is beyond any reasonable argument, but rather is based on preconceived notions of definition of what identity is, and the belief of the moral right that they are indeed as the name indicates "right" in discriminating against persons who do not hold their hold beliefs - beliefs that do not even try to consider that issues concerning sexual preference and sexual identity must be viewed in the background based on biological factors.

In a his paper "Sex and Gender Are Different: Sexual Identity and Gender Identity Are Different" Dr. Milton Diamond writes of the differing terms of sex, sexual identity, gender and gender identity and the value of this understanding "particularly seen when reference is made to individuals of various minority groups such as transsexuals, intersexuals or others." ${ }^{38}$ Dr. Milton goes on to say that the "terms heterosexual, homosexual and bisexual might better be used as adjectives rather than nouns since the terms too often label individuals as if that is the total aspect of their character rather than just representing one facet of their personality and life. . . [T] hat caveat might also be extended to all the other terms often used as labels for people. One is not simply a lesbian, or transvestite or transsexual any more than one is simply a teenager, a Jew, a political Green or plumber. Life and character are complicated, and it is clinically and socially better and wiser to acknowledge this diversity (emphasis added). Clients, children as well as adults, will appreciate this recognition. The danger is that individuals so labeled might, themselves, come to see only that facet of self and limit or deprive their life of other aspects of meaningful expression. Or they might think they then have to conform to some model of group stereotyped behavior." In these remarks, this researcher has given an understanding to the issues that our laws have not yet seemed to address -- issues of limitations to people and deprivation to people's lives of "meaningful expression." 39 The "danger" he expresses are these limitations and deprivations.

\footnotetext{
${ }^{32}$ ROGER E. MEINGER, AL. H. RINGLEB \& FRANCES L. EDWARDS. THE LEGAL ENVIRONMENT OF BUSINESS 385 (13 ${ }^{\text {th }}$ ed. 2018). See Also Courtney Joslin, "Protection of Lesbian, Gay, Bisexual, and Transgender Employees Under Title VII of the 1964 Civil Rights", Acthttps://www.americanbar.org/publications/human_rights_magazine_home/human_rights_vol31_2004/summer2004/irr_ hr_summer04_protectlgbt.html.

${ }^{33}$ Id.

${ }^{34}$ Pricewaterhouse v. Hopkins, 490 U.S. 228 (1989).

35 "Are tides changes in favor of prohibiting sexual orientation discrimination under Title VII? Denver Labor Law. (201), 8 https://denverlaborlaw.com/2018/03/05/are-tides-changes-in-favor-of-prohibiting-sexual-orientation-discrimination-undertitle-vii/.

${ }^{36}$ Civil Rights Amendments Act of 1975, H.R. 166, 94th Cong. (1975).

${ }^{37}$ Supra note 1.

${ }^{38}$ Milton Diamond, PhD, "Sex and Gender Are Different: Sexual Identity and Gender Identity Are Different”, University of Hawaii, John A. Burns School of Medicine, Department of Anatomy and Reproductive Biology, Pacific Center for Sex and Society, Clinical Child Psychology and Psychiatry - Special Issue in Press for July 2002.

${ }^{39}$ Id.
} 
The idea that he presents is that certain individuals most somehow be made to "conform" to some stereotyped model that not only proponents of prohibitions of same-sex marriage laws set out, but also that the laws uphold such discriminatory stereotypes that deprive others of their rights and freedom of choices. ${ }^{40}$

\section{The Supreme Court of the United States}

As the states struggled to define same-sex marriage, either allowing or prohibiting, and to allow or disallow domestic partnerships, civil unions and contractual cohabitation, members of our society were treated unequally as their ability to be legal involved in same-sex marriages. In the backdrop of the struggle of states, advocates against and proponents for recognition of life choices and decisions regarding family and civil partnerships was from a reaction by U.S. Supreme Court's in the form of a roaring silence. Although looking at the same-sex marriage issue in Obergefell v. Hodges, ${ }^{41}$ there is still silence, either in the rationale or any affirming opinion that there still remain issues in such legislation exemplified in Title VII. As the pendulum swings back and forth for-and-against discrimination based on sexual identity and sexual preference, the Supreme Court continues to be unheard. As a result, in the U.S. there is no across the board treatment of the lesbian, gay, bisexual and transgender (LGBT) people in broader areas outside the marriage concept itself. In essence it appears that the Supreme Court chose to deal with a narrow issue of same-sex couples and yet missed an opportunity to give equal treatment in other realms of our society such as the workplace. It appears that the political and emotional appeals of differing groups that struggle to continue to define other people's rights and liberties are still more the norm than not when it comes to legal prohibitions concerning discrimination. The outcome is that the U.S. is now a country divided on an equality issue that could well fall within a $14^{\text {th }}$ Amendment and a Title VII antidiscrimination interpretation by the Supreme Court that could place an end to the controversy. Although Title VII denounces discrimination based on sex, the U.S. Supreme Court refuses to speak concerning discrimination based on sexual preference or sexual identity. And although the $14^{\text {th }}$ Amendment speaks to equal protection under the law, it appears that our courts are reticent to equally protect individuals' choices outside this institution of marriage and the narrow interpretation under DOMA. ${ }^{42}$

Previously the U.S. Supreme Court had left to the states domestic matters. ${ }^{43}$ The earlier silence of the court in regard to same-sex marriages and civil unions would, on the surface appear to coincide with this approach to domestic law. However, what the Supreme Court seems to fail to recognize is that the discrimination against same-sex couples is not a mere domestic matter concerning issues such as the length of separation before filing for divorce, or emancipation ages that allow certain couples to wed at a young age. Instead, the issue is one of discrimination, not one centered solely of "marriage". Title VII clearly had the ability to address the same-sex civil union issue, but the Supreme Court's addressing of this crucial area in Obergefell v. Hodges regarding the treatment of certain U.S. citizenry has been but a whisper on a controversial legal subject.

\section{Has The Supreme Court Addressed State Statutes Concerning The Broader Areas Of Same Sex Activities?}

Despite Obergefell $v$. Hodges the most that the court has done is skirt the issue of treatment of homosexuals and other same-sex issues. Despite the state courts grappling with this issue, no leadership by the higher court has come through and the cases that the Supreme Court has addressed in this area few. In Lawrence v. Texas, the Supreme Court held that the Texas statute that created a crime when a same-sex couple engaged in intimate sexual conduct was unconstitutional. In this case, the act was consensual sodomy engaged in the privacy of a home. ${ }^{44}$ In an earlier case of the constitutionality of Georgia's sodomy law, the Supreme Court held that the fundamental rights of homosexuals were not violated by the Georgia statute. ${ }^{45}$ In Republican Party of Minnesota v. White, the Supreme Court touched on the same-sex marriage issue regarding statements that candidates for political election may or may not say regarding their views on same-sex marriages while running for office. ${ }^{46}$ In a negative opinion concerning homosexuality and discrimination, the Supreme Court in Boy Scouts of America v. Dale looked at a case in which a scoutmaster was expelled after declaring he was a homosexual, but upheld Boy Scouts' $1^{\text {st }}$ Amendment right of freedom of association to expel the scoutmaster. ${ }^{47}$ Same-sex harassment discrimination has been held actionable in a discrimination lawsuit under Title VII in Oncale v. Sundowner Offshore Services, Incorporated. ${ }^{48}$

\footnotetext{
${ }^{40} \mathrm{Id}$.

${ }^{41}$ Supra note 1.

${ }^{42}$ Supra note 1.

${ }^{43}$ Supra notes 17 and 18.

${ }^{44} 539$ U.S. 558, (2003).

${ }^{45} 278$ U.S. 186 (1986).

${ }^{46} 536 \mathrm{I} / \mathrm{S} / 765$ (2002).

${ }^{47} 530$ U.S. 640 (2000).

${ }^{48} 523$ U.S. 75 (1998).

44
} 
However, the Court kept this decision well within the confines of sexual harassment, and did not open the rationale to other areas of discrimination, such of that of domestic relationships. What of these cases and holdings now? Do they still stand in an odd contradiction to Obergefell v. Hodges? Instead of widening the opinion to cover other areas of discrimination, it appears the Supreme Court decided to approach the whole subject matter in one single area of state laws and state courts' decision-makings. In looking at the make-up of the U.S. Supreme Court, it is not surprising that there is reticence in granting civil rights to same-sex couples at a time when this legal issue is coming into full light. In 2013, the majority of five out of the last nine Supreme Court justices had been appointed by Republican presidents, and leaving four appointed by Democratic Presidents Clinton and Obama. ${ }^{49}$

\section{Conclusion}

Prohibitions against same-sex marriage reeked of discrimination. As the Jim Crow Law and the Anti-Miscegenation Laws have been struck down by courts and thrown into the archives of history, so has the anti same-sex marriage laws. However, the related infringements on individual freedoms in the country still are unaddressed by the Supreme Court of the United States. The treatment of same-sex couples had become indeed the $21^{\text {st }}$ Century's challenge of a progressive society. However, the final bastion of discrimination of the LGBT community still exists in many other arenas. Perhaps the American people will once more be aware that the United States may not be the "home of the free" in their decision-making and the "land of the brave" -- those courts and individuals brave enough to accept those of differing faiths, beliefs and relationships in our society. As well-stated in a radio broadcast entitled "Families Without Borders" disavowing South Carolina's Amendment $1^{50}$ a young University of South Carolina student stated an overriding concern of how we treat different people in this society:

My family has never been confined to the standard of only one father and one mother. That is to say, I feel that I have had numerous fathers and mothers, all unrelated by blood, all of whom I incorporated into the concept of family throughout my life.

I have a godfather, an old friend of my father, a stout Italian man with a sort of Mafioso look hindered only by an excess of Argyle sweater-vests in his closet. He runs a small bar in an old mountain town in the north of Italy as a means of supporting his family, by which I mean not only his mother, his wife and his daughter, but the whole of his small community, the members of which gather at his bar and celebrate among themselves as a family would, all of them brothers and sisters of a single borderless entity. As my own family entered into the world of this establishment, we were incorporated into the community of new relatives.

Later my family broke apart. My parents divorced and my mother and I moved back to America. We were at this time financially unstable, and while waiting to make our own home, were incorporated into the family of another, a generous couple of professors, my mothers' friends, who incapable of bearing their own children were happy to extend their family.

To them, my mother was a mutual sister and I was a son. The three adults of this family would help me in my school work. We would cook meals, have movie nights and do all the sorts of things a family of normal operation might, only our exception being that we were a family made of one father, two mothers and a child.

When my mother and I had our own home, we discovered family in an elderly couple down the street. The wife of the couple was a child in Berlin during the Second World War and the husband was a New England man who daily would record the more humorous accounts of their times together in the form of poetry.

As we developed our relationships together, he also began writing for my mother and me affirming our sense of a family entity. His wife refers to me to this day as "her son" engaging frequently in joking arguments with my mother over my custody.

The oldest member of this sort of undefined family of mine is a Chinese woman who when I was three would help take care of me while my parents worked. She has a tape, a sort of a family video, that she showed me more recently. In it she and I sit at her dining table with her mother and father. We prepare food, breaking eggs and snapping peas while we all speak to one another in Chinese.

\footnotetext{
${ }^{49}$ See Table 1. https://www.supremecourt.gov/about/members.aspx.

${ }^{50}$ In 2006 South Carolina Amendment 1 amended the South Carolina Constitution to make it unconstitutional for state to recognize same-sex marriage or civil unions. In addition, it made unconstitutional for anyone to perform such marriages or unions. p. 24 No. 554 edition of the Journal of the Senate of the State of South Carolina. (2005). This law passed by an 82 to 0 vote defining marriage as between one man and one woman. The South Carolina State Senate, on a voice vote, passed the bill.
} 
I remember my surprise at this not only because that I had not known at any point that had I been capable of speaking Chinese, but because of the memory of her parents came rushing back to me, their effect on my life, capable of a sort of an indefinable permanence that no memory of language could compare to.

Now my friends are becoming incorporated into my family, each of them with time becoming a sort of brother or sister. We become a new generation of a great and borderless human family incapable of either definition or limitation. We have come to address one other with these sorts of love; someone is "our family," someone that is "ours."

I lived recently with an old pair of my friends a couple who recently became engaged. During that time, we came to develop into the form of a family, a unit. In the acknowledgement they light heartedly call me "their gay." They are "my straights".

In this way we have moved to infiltrate the borders of the common family as I have found throughout my life that individuals of all walks of life seem to speak to--to create human connections, close connections, connections unbound by legal restrictions and instead unifying in its many capabilities.

My family never has been confined to the standard of one father and one mother. It never will. By this I mean that no relations of blood or law have defined my family so much as the relations made capable by love and by free will. This borderless quality of love and family is not specific to homosexual nature but extends itself to the interactions in social forms of all human kind.

It saddens me then when the state in which I live attempts to exploit the powers of law to support blatant acts of discrimination in spheres of love and family. No benefit comes from such an act. Benefit I have found derives in the shape of unity and the exploration and discovery of family in our world.

What reason, what motivation do individuals have to judge and prohibit any class of citizen, any human assembly in their celebration of an act of love? What good and what unity can come from such a discrimination?

Let us work to establish families not to divide and prohibit them. Let us recognize the bigotry and the injustice of whomever may work to strive against such a vital cultural establishment as family.

Let us - love. ${ }^{51}$

Table 1 Make-Up Of Supreme Court Justices $2013^{52}$

Justices Nominated by Republican Presidents

Samuel Alito

Anthony Kennedy

John G. Roberts

Antonin Scalia

Clarence Thomas

Justices Nominated by Democratic Presidents

Stephen G. Breyer

Ruth Bader Ginsberg

Elena Kagan

Sonia Sotomayor
President Who Nominated

George W. Bush

Ronald Reagan

George W. Bush

Ronald Reagan

George H.W. Bush

President Who Nominated

Bill Clinton

Bill Clinton

Barak Obama

Barak Obama

\footnotetext{
${ }^{51}$ Jayme Ringleb, "Families Without Borders", University of South Carolina and intern with Fairness For All Families Campaign. 2006. c:Iprogram fileslqualcommleudoralattach JaymeRingleb_commentary1.mp3.

52 https://www.supremecourt.gov/about/members.aspx. 